\title{
釧路港における港湾空間の発達過程
}

\author{
酒井多加志*

\section{Geographical Study on the Development of Port Space at Kushiro Port} \\ Takashi SAKAI *
}

\begin{abstract}
The purpose of this study is to elucidate the formation process at a port space of local port. This kind of study is rare in geographical research, although ports have been greatly transformed in recent years. This study chiefly analyzes the issues of transportation mode and industrial structure in the port hinterland. Kushiro port, which is the largest port in eastern Hokkaido, is the selected study area. In this study, the following become clear.

At the beginning of reclamation, the head of a bay or a river mouth that had the calm waters was used for a port. For example, Kushiro Port, which is situated at the mouth of the Kushiro River, began to operate as port in the Edo era, and developed by incorporating its river valley into the hinterland. At that time, port was a stage on the trading beach. Mother ships could not reach the coast directly, because there were no loading facilities such as quays and loading machines. Therefore, cargoes were transported between mother ship and beach by barge.
\end{abstract}

A railway constructed from the port to the hinterland brought a large amount of cargo to the port. Port space was demanded in response. Then, instead of the past trading beach, a quay where barges were able to come alongside safely was constructed and the rail cargo line was connected to it. As the quay was constructed on the assumption of railway transportation, integration of railway and port was brought about. Hence, the town became separated from the port by the railway. In Kushiro, barge quays progressed along both sides of the Kushiro River, which had calm waters. This expanded the port space to the river area.

After World War II, urgent reclamation and economic growth brought rapid development of industry, and exports increased. Transport networks, whose main transportation mode was rail, developed further. The port responded to the increasing cargoes by constructing a pier along the coast in front of the town. Mother ships could then come alongside the pier. As this pier was constructed on the assumption of mass railway transportation, a large site for railway transportation was prepared at and behind the pier. This separated the port from the town. On the other hand, most of the former quays were deprived of loading functions and gradually declined. In Kushiro Port, two new piers were constructed along the coast in front of the urban area, and most of the quays along the Kushiro River declined. Kushiro Port in this era had the following features. The ratio of rail transport facilities occupying the port space

* 北海道教育大学教育学部釧路校

* Kushiro Campus, Department of Education, Hokkaido University of Education 
was large. Rail transport facilities separated the port from the urban area. The vast storage facilities for coal, which reflected the industry in hinterland, were located behind the loading facilities.

Motorization, which started from about the mid-1960's, brought the development of the road network and the decline of the railway network. Rapid economic growth changed the industrial structure in the hinterland. The development of motorization and changes in the industrial structure in the hinterland caused the port to respond by constructing a new port adjacent to the former port. This new port has the following characteristics. Large transportation spaces are prepared behind the piers for to truck transportation. Each pier is specialized for an industry in the hinterland. For example, each new pier of Kushiro Port specializes in oil industry, paper industry, and dairy farming.

Port functions moved consecutively from the old port to the new port. With the construction of the new port, the port space of the old port was reorganized. Port space near CBD became the target of waterfront development in Kushiro. New commerce, business, culture, and sightseeing facilities were constructed there. The loading function of the old port is seen at both ends of the old port; however, in the greater part of the port space, sheds and warehouses became obsolete. Unoccupied space and parking space extend to the area behind the sheds and the warehouses, which are extensively use land.

Key words : port space, hinterland, rail transport, motorization キーワード : 港湾空間, 背後圈, 鉄道輸送, モータリゼーション

\section{I. 序 論}

\section{1）従来の研究と研究の方法}

“港湾”という用語は “ports and habours”の 邦訳であり，明治期に入ってから用いられるよう になったとされる。前者の“port”は交通地理学 的な, 後者の “harbour” は自然地理学的な意味 合いが強い。すなわち, “port”は海上交通と内陸 交通とを結びつける交通結節点を指し，そこには 泊地と埠頭を中心とした陸上・水上の空間が含ま れる。これに対して, “harbour”はもともと船舶 を安全に停泊できる天然の泊地を指していた。後 に，人工の構造物によって囲まれた泊地も含むよ うになったため, 現在は単に船舶を安全に停泊で きる泊地として捉えられている（山口，1980，12)。

港湾に関する研究は, 地理学のほかに経済学, 歴史学, 工学など様々な分野で行われている。ま
た, 地理学においても交通地理学, 都市地理学, 商業地理学, 歴史地理学, 工業地理学などにおい て研究例がみられる。このように港湾研究は様々 な分野からのアプローチが可能である。

港湾空間に関する研究は外国において多くみら れる。先駆的な研究として, Hance らの発展途上 国を対象とした一連の研究 (Hence and van Dongen, 1956, 1957, 1958a, b) がある。各研 究において港湾の土地利用, 輸出貨物の背後圈, 港湾と背後圈間の輸送について明らかにされてい るが，各々の関連にまでは言及されていない。ま た, Kenyon（1968）は港湾と臨港地区の詳細な 土地利用調査を行い, 港湾空間の構造を明らかに している。その中で港湾隣接地区を漸移地帯とし て捉えている点が注目される。さらに, Forward （1967，1969）は研究対象を港湾機能を伴わない 都市沿岸部を含んだウォーターフロントにまで広 げ，ウォーターフロントの土地利用の変化ならび 
にウォーターフロントの比較を行っている。この 中で港湾空間の変化をもたらす要因として, 輸送 の効率化を取り上げている。このことに関して Wallace（1975）はコンテナ輸送に着目し，コン テナリゼーションが港湾に与えた影響について言 及している。

港湾空間の発達に注目したものに, Bird (1963) の先駆的な研究がある。Bird はイギリスの河口港 を調査し, 河口港の発達を 6 段階に分類している。 この中で港湾の発達に伴い都市と港湾が次第に分 離していくと述べている点が注目される。都市と 港湾の関係に関しては，オーストラリアを対象に した Scott（1959）の研究にもみられる。この研 究では港湾と都市が一体化したものとして捉えら れているが，これはイギリスとオーストラリアの 港湾の歴史の違い, あるいは河口港と海港の違い を反映したものであろう。また, Rimmer (1967a, b, c) は港湾の発達段階のモデルを構築し, ニュー ジーランドおよびオーストラリアにおいて検証を 試みている。このモデルでは成長した港湾が最後 に離心化する，すなわち専門化した機能を持つ港 湾が分離する，という段階を設けている点に特徵 がみられる。近年では, Wrenn（1986）が港湾と 背後の都市の発達過程，および相互の関係をパ ターン化している。この中で港湾と都市の分離に ついて言及しているが，分離の要因としてコンテ ナ化をあげている。このコンテナ化に対応した港 湾の分離は, Rimmerのモデルで示された専門化 した機能を持つ港湾の分離の一事例として捉える ことができる。

このように外国においては，過去に港湾空間の 実証研究が多くみられた。しかし，近年は港湾が 大きく変容したにもかかわらず，地理学の分野に おいてこの種の研究はあまりみられない。

一方，日本においては，港湾空間に関する研究 は柾 (1968), 河地 (1974), 今野 $(1970,1983)$, 遠藤 (1986), 伊藤 (1995), 柴田（1998）など にみられる。しかし，これらの諸研究は実証的な 研究ではなく, かつ港湾の空間的側面よりも機能 面について言及したものである。港湾空間を実証 的に研究したものは奥平・南 (1966), 奥平 (1967),
渡辺（1971）にみられるだけであり, 近年この種 の研究はみられない。一方, 漁業空間としての港 湾に関しては, 近年, Shinohara（1992）や佐藤 ほか（2000）の研究がみられる。

以上の港湾空間に関する諸研究においては, 港 湾の空間的概念についてはあまり議論がなされて おらず, 結果として研究対象としての港湾空間の 捉え方は研究者によって異なる。この港湾の空間 的概念について, 北見 (1993) は機能的関係から 考察し, 港湾および背後の地域を, 港の機能を中 心とする一次的地域, 港湾都市を中心とする二次 的地域, ヒンターランド (背後圈) ${ }^{1)}$ である三次 的地域の 3 地域に分類している。このうち一次的 地域は港湾法および都市計画法で定める港湾区域 と臨港地区（図 1） ${ }^{2)}$ を指すと考えられるが, 本研 究での港湾空間はこの一次的地域および二次的地 域のうち一次的地域に隣接し, かつ生産・流通面 で港湾との結びつきが強い地域を含むものとする。 なお，北見の一次的地域には，物流を伴わない ウォーターフロント開発地域が含まれないが，港 湾空間の発達過程を考察する上では不可欠である ため, 本研究ではウォーターフロント開発地域も 対象地域に含むことにする。

以上みてきた従来の諸研究の成果を踏まえ, 本 研究では, 背後圈との関係から地方の港湾空間の 形成過程および港湾空間に変化をもたらした要因 を明らかにすることを目的とする。港湾空間の形 成過程については, 港湾背後圈の輸送ネットワー クとの関係から考察された研究はいくつかみられ るが, 背後圈の産業構造との関係から考察された ものはあまりみられない。そこで, 本研究では港 湾空間と背後圈の産業構造との関係についても考 察していく。

研究の方法は以下の通りである。第 II 章では, 「釧路港建設史」および各種古地図を基に港湾の土 地利用図を作成することによって, 近代化以前の 港湾空間の形成過程を明らかにする。なお，ここ での近代化以前の港湾とは艀輸送に依存している 港湾を指す。第章では, 港湾近代化以降の港湾 空間を鉄道輸送時代と貨物自動車輸送時代に分け て明らかにしていく。事例として 1968 年と 1998 


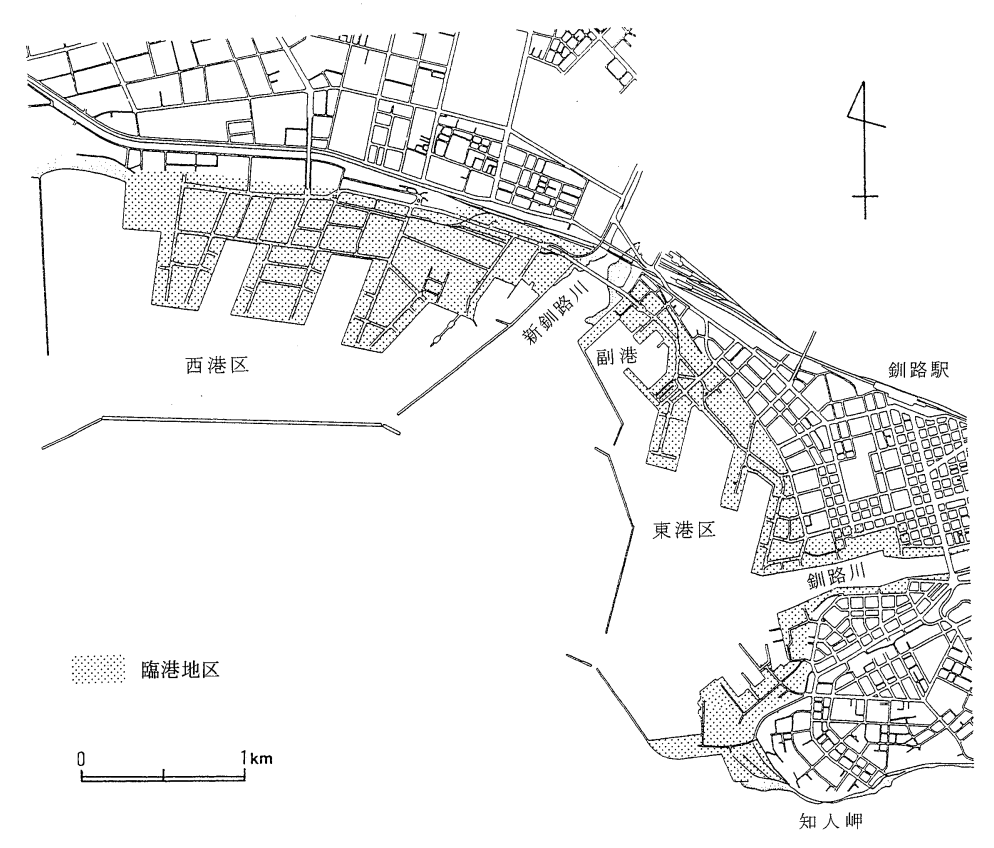

図 1 研究対象地域.

Fig. 1 The study area.

年を取り上げたが，これはこの間，釧路港の背後 圈の輸送手段と産業構造がともに大きく变化した ことによる。すなわち, 主要輸送手段が鉄道から 貨物自動車へ, 港湾取扱貨物が移出指向から移輸 入指向へと変化している（酒井，1996）。港湾の 土地利用図は住宅地図, 釧路市港湾部発行の港湾 計画図, 空中写真, 住宅地図および土地利用調查 によった。第 $\mathrm{I}$ 章では，1968 年と 1998 年の港湾 空間を比較することによって，新港建設に伴う旧 港の港湾空間の再編について明らかにする。

研究対象港湾として釧路港を選定した。これは 釧路港が開拓期から現在に至るまで, 北海道東 部 ${ }^{3)}$ の拠点港としての地位を維持してきたが, その ため, 地方の拠点港としての港湾空間の変化を時 系列的に捉えていくことが可能であることによる。 また, Bird やWrennの港湾の発達モデルは大規 模な港湾を対象としたものであり, 地方の中小規 模の港湾を対象としたものではない。すなわち， 大規模な港湾はWrennのモデルにみられるよう に近年コンテナ貨物への対応が著しいが，このよ
うな港湾は日本では東京港, 横浜港, 名古屋港, 大阪港, 神戸港など特定の港湾に限られる。一方, 釧路港をはじめとする大部分の地方の港湾では, コンテナ貨物の取扱量は多くない。従って, 釧路 港を研究対象にすることによって地方港湾の港湾 空間の発達過程を解明することができるものと考 えられる。

\section{2) 研究対象地域の概観}

釧路港は苫小牧港, 室蘭港に次ぐ貨物取扱量を 有する北海道東部最大の港湾で, 1950 年の港湾 法制定とともに重要港湾に指定された。1998 年 度の取扱貨物量（フェリーを除く）は 19,433,331 トンで, 北海道全体の $17.9 \%$ 占める。取扱貨物 量のうち, 移出が $35.6 \%$, 移入が $39.4 \%$, 輸入が $24.9 \%$ 占めているのに対して, 輸出は全体の $0.1 \%$ 占めるにすぎない。主要取扱貨物は, 移出 が石炭, 生乳, 紙・パルプ, 移入が石油製品, 重 油, セメント, 輸入がチップ, 石炭, 動植物性製 造飼肥料となっている。

釧路港の港域は新釧路川を挟んで東港区と西港 
区に分かれる（図 1）。東港区は釧路川の河口付近 を中心に知人岬から新釧路川にかけてを港域とす る。東港区内の西に位置する副港は漁港として機 能している。魚の水揚げ量は 1979 年から 13 年間 日本一であったが，その後，イワシやサンマ等の 水揚げ量が減少し, 1997 年には第 6 位まで低下し た。新釧路川の西に位置する西港区は, 1974 年に 第一石油栈橋が使用を開始して以来, 1998 年現在 に至るまでに，第一埠頭と第二埠頭が完成し，第 三埠頭も一部を除き使用を開始している。

釧路港の位置する釧路市は人口 19 万 9 千 $(1995$ 年国勢調查）余りを有する北海道東部最大の都市 であり，経済・文化・政治の中心的機能を担って いる。三大基幹産業といわれる石炭業・製紙業・ 漁業とともに発展してきたが, 近年は内外炭の炭 価格差に伴う炭鉱存続問題，全国的な製紙業の生 産設備過剩に伴う工場の再編問題，イワシを中心 とする漁獲量の減少, などの諸問題を抱え, 経済 は停滞気味である。また，人口も 1981 年の 21 万 8千をピークに減少傾向にある。

\section{II. 港湾近代化以前の港湾空間}

\section{1）交易浜時代の港湾空間}

江戸時代の釧路はクスリ場所 ${ }^{4)}$ と呼ばれ,ここで アイヌ人と松前藩との間で交易が行われていた。 クスリ場所での交易品は周辺の沿岸域で採取され た昆布および鰊や鮭の加工品（鰊粕や塩鮭など） が中心であった ${ }^{5)}$ 。一方, 内陸との交易は鹿皮など わずかにみられる程度であった。このことから， クスリ場所の交易圈は場所の周辺付近に限られて いたといえる。

この頃の釧路港はクスリ泊と呼ばれ，知人岬か ら釧路川河口までのやや湾入した海域が本船の泊 地として利用されていた。これは当時のクスリの 海岸部に本船が直接接岸できる港湾施設がなかっ たことによる。そのため, 釧路川河口部の左岸か ら張り出していたタダイトと呼ばれる砂嘴から知 人岬に至るまでの知人浜が主に艀の船着き場とし て利用され，貨物は艀によって本船との間を運搬 されていた。従って, 当時の釧路港は自然浜で荷 役が行われる交易浜の段階であったといえる。知
人浜の背後には場所経営の中核施設である会所が あり，その周辺には小規模ながら集落が形成され ていた。この知人浜は漁船の船揚場, 昆布や魚の 干場としても利用されていたことから, 背後の集 落は漁村的色彩も強かったといえる。

明治時代に入ってもクスリ泊には大きな変化は みられなかったが，1887（明治 20）年に安田財閥 による硫黄採掘事業が屈斜路湖の東に位置する川 湯硫黄山において開始されると, 大量の硫黄が釧 路川の小型蒸気船により釧路川河口部にもたらさ れるようになった。図 2 は硫黄採掘事業の行われ ていた 1890 (明治 23）年の釧路港を示したもの である。硫黄はタダイトと呼ばれる砂嘴の東側で 小型蒸気船から陸揚げされ， タダイト基部に敷設 されたトロッコ軌道によって知人浜まで運搬され た。これはヨダイト付近の水深が浅く, 知人浜ま での小型蒸気船の航行が困難であったことによる。 知人浜には硫黄保管用の倉庫が設置されており, ここから硫黄は艀により沖合に停泊する本船へと 運搬された。また, 春採湖畔に開鉱された安田炭 鉱と知人浜の間には馬車軌道が敷設され, 石炭が 知人浜まで運搬された。石炭は釧路港に寄港する 外洋船の燃料および内陸部での硫黄精錬や硫黄輸 送用の蒸気機関車の燃料として利用された。この ように, 釧路港の陸域側は硫黄事業に特化した港 湾空間がみられるようになった。一方, 知人浜に は港湾荷役施設は整備されておらず，依然として 交易浜の段階であったが, 釧路崎灯台や気象観測 所や函館税関出張所が設置され, 港湾機能は次第 に強化されていった。また，かつて会所のあった 背後の集落には釧路郡役所や硫黄山安田事務所が 置かれ, これらの施設を中心に商業, 業務施設が 集積し, 釧路は次第に都市的性格を有するように なった。1 1890 年には戸数 1,163 , 人口 4,232 に達 している。安田の硫黄採掘事業は採掘開始から 10 年後に中止されるものの, 釧路発展の経済的基盤 を築くとともに内陸部へのゲートウェイとしての 性格を強めることになった。

\section{2）鉄道開通後の港湾空間}

1901 (明治 34）年に官設鉄道釧路線が開通した が，起点となる釧路駅は釧路川河口部の右岸に設 


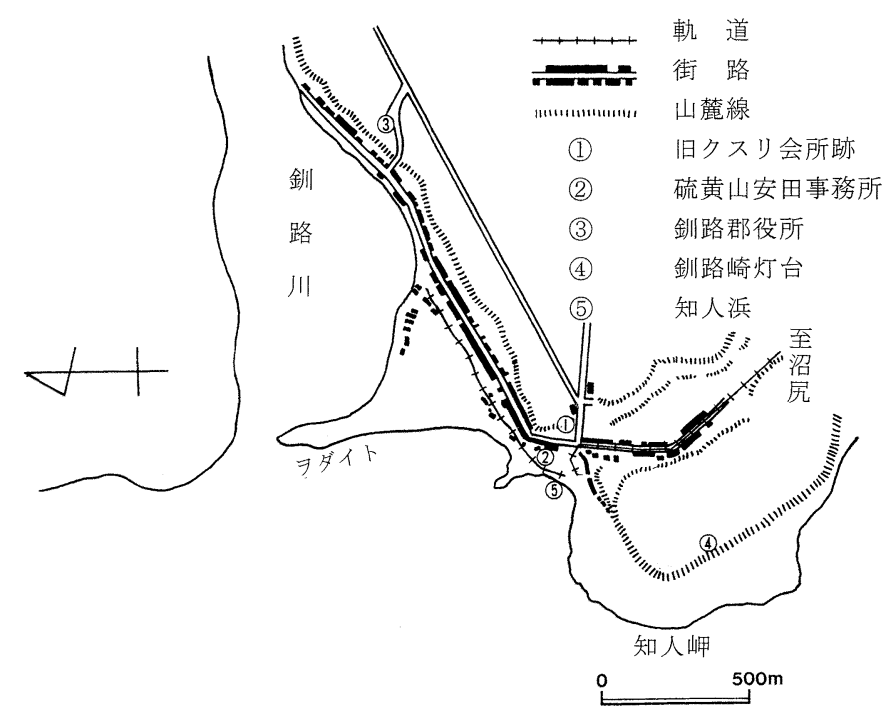

図 21890 年の釧路港.

(C.S.メイク：「釧路港改修計画図」より作成)

Fig. 2 Kushiro port in 1890.

置された。釧路駅周辺には鉄道官舎の他，運送業 者や荷役業者の店舗と倉庫が集まり，闑散とした 漁村であった釧路川右岸に，新たに碁盤の目状の 整然とした市街地が形成された（図 3)。鉄道開通 後, 人口は急増し, 1903 (明治 36) 年には戸数 2,570 , 人口 12,010 に達している。

鉄道の開通は釧路港の港湾空間をこれまでの釧 路川河口部の左岸から右岸へと拡大させた。すな わち, 右岸では河口部を埋め立てることによって 鉄道貨物ターミナルと艀用の岸壁（錦町岸壁）が 整備された。これは従来の交易浜では鉄道からの 大量の貨物に対応できないことによる。知人浜抒 よび釧路川河口部の左岸においても埋め立てが進 められ, 艀用の岸壁が整備されるとともに, 背後 の市街地も拡大した。

大正時代に入ると, 内陸部の開拓の進行と鉄道 網の整備により，釧路駅 ${ }^{6)} に$ 北見・十勝方面から 大量の農産品と林産品がもたらされるようになっ た。これらの貨物は貨物線を通じて釧路川河口部 右岸の岸壁まで搬送され, 林産品は土場で, 農産 品は倉庫で保管されるようになった。そのため, 河口部右岸の港湾空間は木材土場や農産品の倉庫
などの保管施設が卓越するようになった。

大正時代末には鉄道網の整備とともに港湾空間 に占める鉄道施設の比重が次第に大きくなってき た。例えば，1922（大正 11）年に釧路川河口から $3 \mathrm{~km}$ 上流の右岸に雄別炭磺鉄道新釧路駅が設置 され，雄別炭礦の石炭はここから艀によって釧路 港の泊地に停泊している石炭輸送船まで運搬され た。翌年には釧路川左岸に官設鉄道根室線天䀂駅 が設置された。天寧駅には北海道東部で産出され た木材が集荷され，駅周辺には木材土場の他，製 材工場や製品を加工する木工場が集まり，産業集 積がみられるようになった。木材は釧路川の河畔 で筏に組まれ, 釧路港の泊地に停泊している木材 運搬船まで運搬された。また, 1925 (大正 14）年 には釧路臨港鉄道が敷設され，太平洋炭礦の石炭 が南防波堤の石炭栈橋まで運搬されるようになっ た。そして 1940（昭和 15）年には官設鉄道の貨 物の一部が釧路臨港鉄道経由で釧路川河口部左岸 の入船町岸壁まで運搬されるようになり, 入船町 岸壁の荷役現場化を強めることになった。

ところで, 昭和初期まで荷役用の岸壁は釧路川 の河口から上流方向に整備されていったが (図 4), 


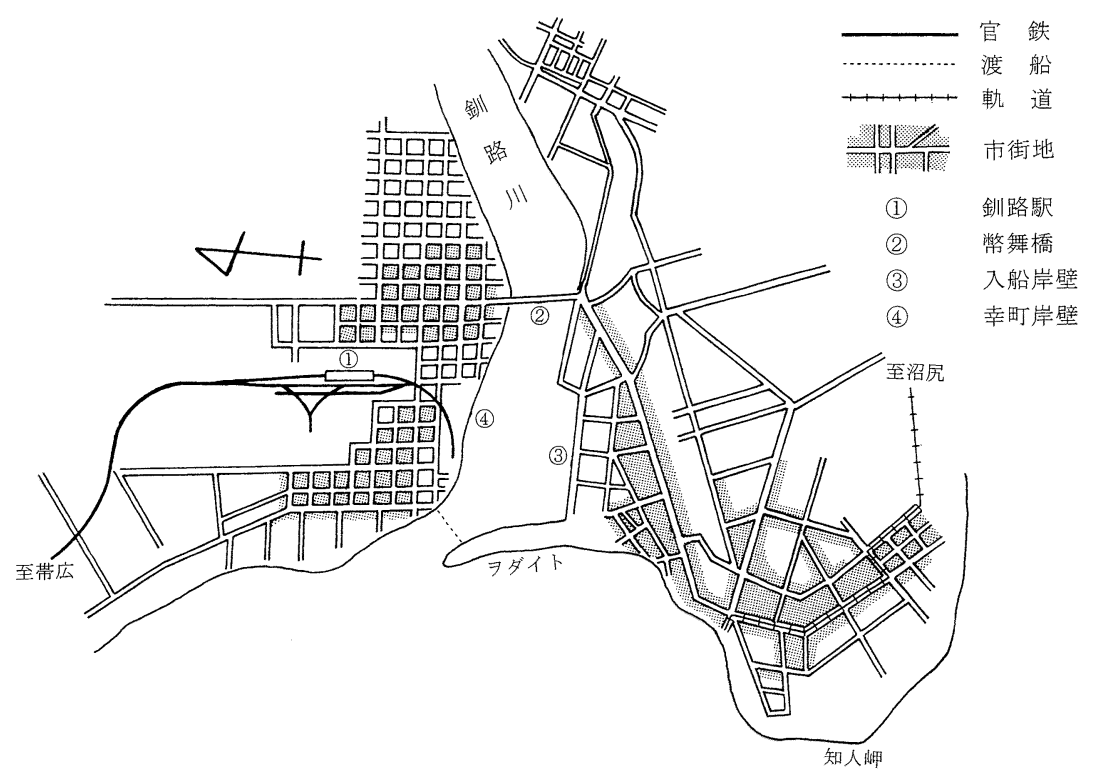

図 31903 年の釧路港.

(「北海道釧路国全図」より作成)

Fig. 3 Kushiro port in 1903.

これは当時の釧路港には南防波堤以外に防波堤が なく, 直接外洋に面した岸壁では艀の安全な接岸 が困難であったこと，釧路川の静穏な水面が艀輸 送に適していたこと，釧路川は背後の鉄道との接 続が容易であったこと，が要因としてあげられる。 その結果，釧路川の河口域は岸壁と本船とを結ぶ 運河の役割を果たすようになった。また，石炭や 木材や農産物などの貨物を中心に，特定の貨物の みを取り扱う専門岸壁化が進行した。これは，釧 路港の背後圈内において石炭業, 林業, 畑作農業 の成長が著しく，それらから発生する貨物量が飛 躍的に伸びたことが一因としてあげられる。

このように明治後期から大正期にかけては，鉄 道と艀用の岸壁が一体化した港湾空間が形成され ていったが，岸壁整備に伴う河岸の埋め立てと岸 壁背後の貨物線の敷設は市街地とウォーターフロ ントとの分離を招いた。その結果, 釧路川河口付 近にみられた漁業集落は, 漁家が釧路市の西部に 位置する千代の浦や港湾開発の行われていない釧 路川の幣舞橋上流側や釧路川河口の西へと移転す ることにより衰退し，一般市街地へと変容して
いった（布施，1994）。また，この時期に整備さ れた岸壁には本船が直接接岸できないため, 港湾 の荷役能力は低く, 一部の貨物は厚岸港で船積み が行われ, 十勝 - 網走方面の穀類の一部は小樽港 へ流れていった。1927（昭和 2) 年から第 2 期拓 殖計画が開始したが, 1929 年の南埠頭の完成によ り, 太平洋炭礦の石炭のみ本船接岸荷役が可能と なった。

\section{III. 港湾近代化以降の港湾空間}

\section{1）鉄道輸送時代の港湾空間}

戦後の北海道東部に掞ける石炭業, 林業, 農業 を中心とする諸産業の急速な発展は, 大量の貨物 を当時の主要輸送手段であった鉄道により釧路港 にもたらした。しかし，旧来の港湾設備ではこれ らの貨物への対応は困難であり, 新たな港湾整備 が求められた。その結果, 本船が直接接岸でき, かつ鉄道輸送に対応した埠頭が, 北埠頭, 副港, 南新埠頭, 中央埠頭の順に整備されていった。こ れらの埠頭と副港はすべて外洋に面しているが, その要因として, (1)釧路川は川幅が狭く, かつ水 


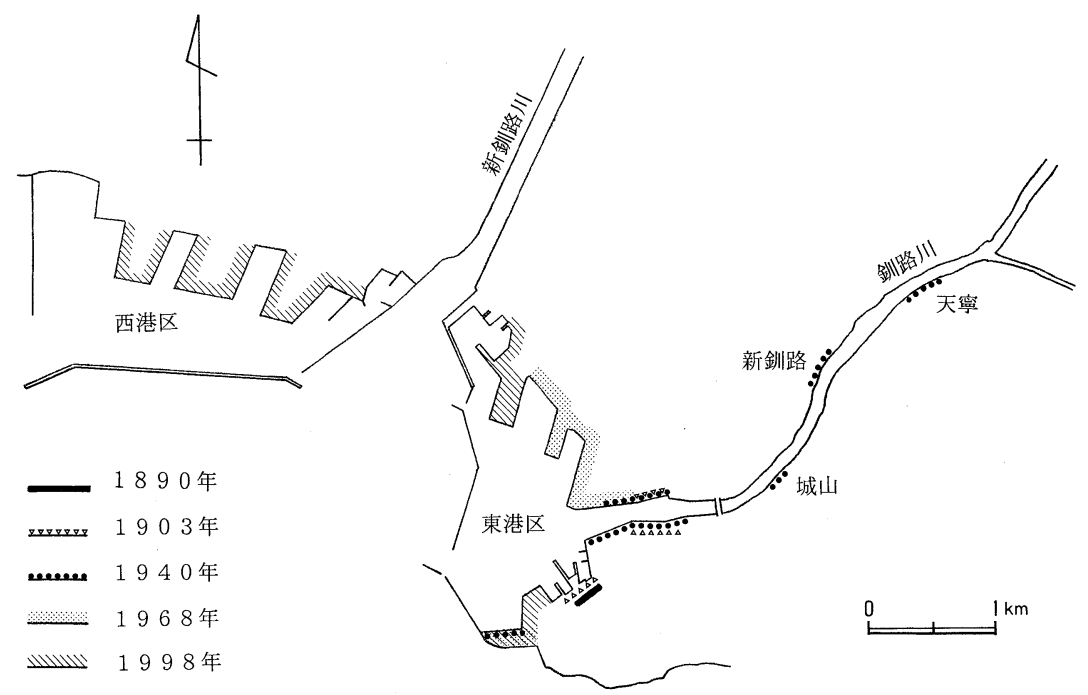

図 4 釧路港における主要荷役岸壁の推移.

Fig. 4 Change of location of main wharf of Kushiro port.

深が浅いため，本船の入港ができなかったこと， (2)釧路川の河岸には市街地が隣接し，本船の接岸 荷役作業および鉄道輸送に必要な空間が得られな かったこと, (3)防波堤が完成し, 海域に静穏な泊 地が確保できたこと，があげられる。一方，釧路 川沿いの岸壁は荷役現場が新たに建設された埠頭 へ移されたことにより，次第に衰退していった。 雄別炭礦の石炭の荷役現場が新釧路駅付近の岸壁 から北埠頭へ移されたのは, その一例である。こ のようにして港湾の荷役現場の中心は河川部から 海岸部へと移動した（図 4)。

1968 (昭和 43）年に最後の中央埠頭が完成し, 釧路港の埠頭整備はほぼ終了した。図 5 はこの中 央埠頭が完成した年の釧路港の土地利用を示した ものであるが，以下，図 5 を基に 1968 年の釧路 港の港湾空間の特徴を埠頭および岸壁ごとにみて い。

南埠頭は前章で記したように, 戦前にすでに完 成しており, 主に太平洋炭礦の石炭が移出されて いたが，同時にセメントの移入や雑貨の移出入も 行われており, 埠頭内にはセメントサイロや上屋・ 倉庫およびこれら貨物と背後圈とを運ぶ釧路臨港 鉄道の引き込み線が敷設されていた。南埠頭の北
に位置する南新埠頭は 1968 年当時整備中であっ たが, 背後には 16 基の石油タンクが設置され, 南 埠頭とともにエネルギー基地に向けての整備が進 められていた。

北埠頭は釧路川以西で最初に整備された埠頭で, 1950 (昭和 25）年に完成した。埠頭背後には貯炭 場が設置され, 雄別炭礦をはじめ白糠町と音別町 にある炭鉱で採掘された石炭は雄別炭礦鉄道に よってこの貯炭場まで運ばれ, 石炭専用船へ船積 みされていた。北埠頭の突堤部にも雄別炭礦鉄道 が乗り入れ, 上屋・倉庫と接続し, 各種貨物の荷 揚げ, 荷降ろし, 保管が行われた ${ }^{7)}$ 。また, 北埠頭 の背後には, 57 基の石油タンクが設置され, 釧路 港最大の貯蔵能力 $(52,200$ トン) を有していた。

以上の南埠頭と北埠頭は炭鉱会社が私有する専 用埠頭 ${ }^{8)}$ であり，石炭の移出を主目的にしていた。 これに対して, 1968 年に完成した中央埠頭は釧路 港で初めての公共埠頭であり，各種貨物が取り扱 われていた。この埠頭は北埠頭の突堤部を進化さ せたものであり，港湾施設は海岸から内陸に向 かって岸壁, エプロン, 上屋, 倉庫と続き, すべ ての上屋と倉庫は鉄道の引き込み線と結びついて いた。岸壁の水深は 9 〜 $10 \mathrm{~m}$ あり, 10,000〜 


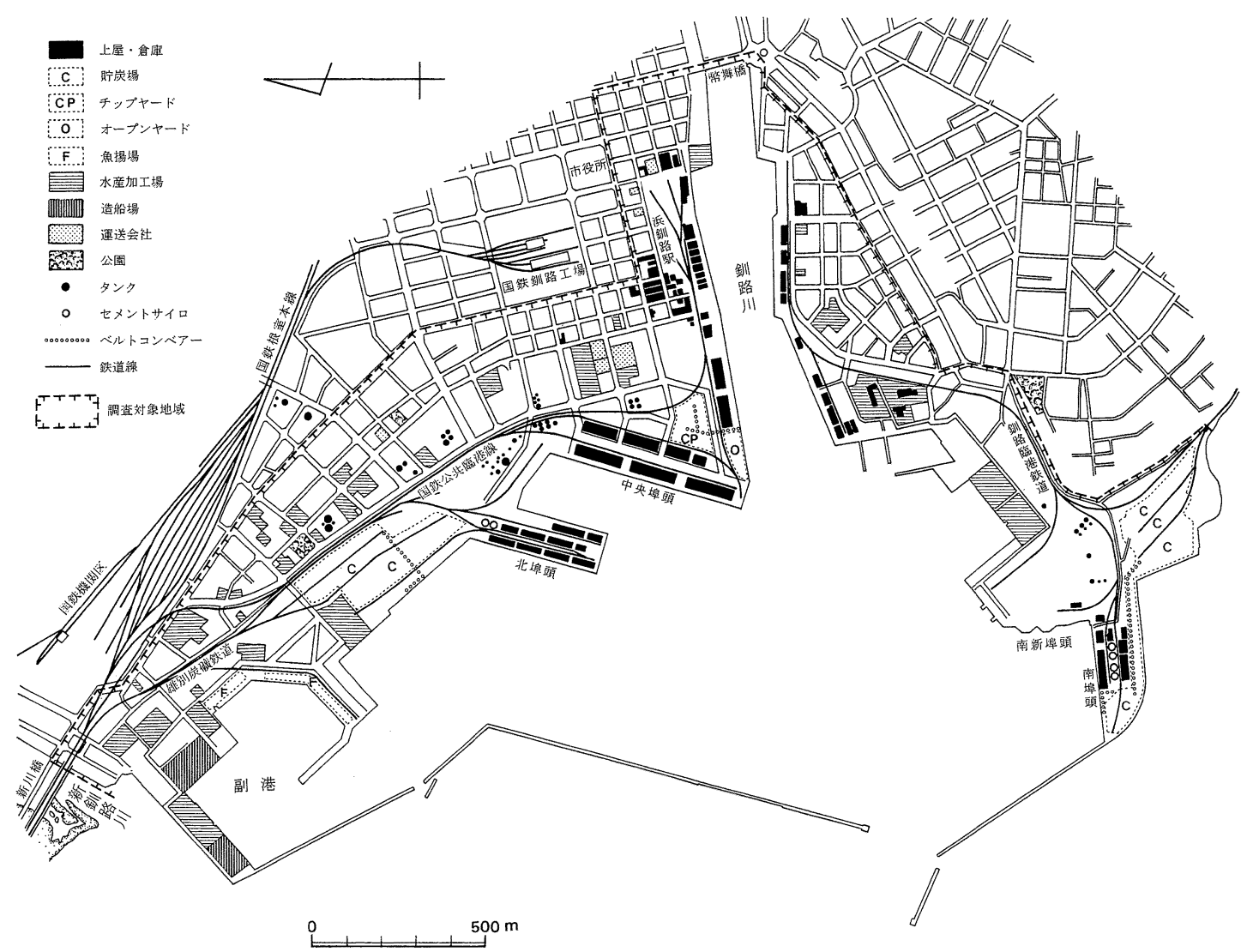

図 51968 年の釧路港の土地利用.（住宅地図および空中写真により作成）

Fig. 5 Land use of Kushiro port in 1968.

15,000 重量トンクラスの貨物船に対応していた。 上屋や倉庫は従来のものより大型化し，埠頭内の 施設は余裕を持って配置されていた。その他，埠 頭内には新たにチップヤードやコンテナヤードが 設置され，岸壁の一部はチップやコンテナを専門 に取り扱う岸壁の専門化がみられた。

以上の釧路港の整備は, 商港としての整備を目 的としていたため，漁港区の移転をもたらした。 すなわち, 釧路川河口部では同じ岸壁で艀と漁船 が荷役作業を行っており, 艀と漁船が錯綜した状 態にあった。そのため, 1937（昭和 12）年に釧路 港の北端に民間人によって漁港 (㛈峨漁港) が建 設され，これにより漁港と商港の分離がある程度 みられるようになった。図 5 にみられる副港はこ
の嵯峨漁港を整備したものであり, 1965 (昭和 40) 年以降, 魚の水揚げはすべて副港で行われるよう になった。副港周辺には大手水産会社（日魯漁業， 日本冷蔵, 極洋捕鯨) の加工場や冷蔵施設が立地 した。大手水産会社 (日本水産, 大洋漁業) は南 新埠頭の北側にも立地していたが, これらは戦後 のサバ, サンマ, クジラの大量水揚げに伴い進出 してきたものである。また, 昭和 30 年代にスケソ ウダラが大量に水揚げされるようになると, 港湾 の背後に位置していた漁業集落の漁家の中に水産 加工に従事するものが現れ, 漁業集落は, 次第に 水産加工業地域としての性格を帯びるようになっ た。

以上みてきた 1968 年の釧路港は, (1)鉄道によ 
る大量輸送を前提としていたため，港湾空間には 広大な鉄道用の用地が確保されていたこと, (2)戦 後の石炭増産政策の結果, 釧路港の背後に位置す る諸炭鉱の出炭量が急増し, 港湾空間に占める石 炭関連施設の割合が大きくなったこと, (3)商港と 漁港の分離がある程度みられるようになり, 漁港 を中心とした漁業および水産加工業に特化した空 間が形成されたこと，に特徵がみられる。

\section{2）貨物自動車輸送時代の港湾空間}

釧路港の整備は中央埠頭の完成（1968 年）を もって完了する予定であった。しかし, 中央埠頭 は北海道総合開発第 1 次 5 か年計画 $(1952 \sim 1957$ 年）において策定されていたため，完成時にはす でにモータリゼーションの進展, 船船の大型化 ${ }^{9)}$, 背後圈の産業構造の変化および経済成長に当時の 釧路港の港湾施設では対応が困難になっていた。 特に 1960 年代中頃に始まるモータリゼーション の進展は著しく, 港湾は鉄道輸送から貨物自動車 輸送に対応した空間が求められるようになった。

背後圈の産業構造の変化には, エネルギー革命 に伴う石炭業の衰退と石油業の成長, 酪農業の成 長, 製紙業の構造変化があげられる。前述したよ

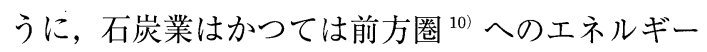
供給基地として釧路港を最も特徴づける土地利用 となっていた。しかし, 石炭業の衰退と石油への エネルギー転換により，港湾は貯炭場にかわって 背後圈への石油供給基地としての役割を担うよう になった。このようにエネルギーが石炭から石油 へ, 移動方向が背後圈から港湾へ向かっていたも のが港湾から背後圈へと向かうようになった。ま た, 北海道東部の酪農業は乳製品の一般家庭への 普及により, 昭和 30 年頃から次第に盛んになっ ていったが, 酪農家の生産規模の拡大に伴い自給 飼料だけでは不足するようになり, 飼料の輸入が 必要となった。そこで, 新たに飼料の輸入, さら には乳製品の移出に関連する施設が港湾に求めら れた。製紙業に関しては, 従来の製紙工場は原料 産地立地型であり, 港湾の役割は製品の出荷が主 であった。しかし, 1954 年の洞爺丸台風は多くの 倒木林を出し, 以後道産材の原木供給が困難に なったこと, 紙・パルプの原料に安価な輸入チッ
プの使用を開始したこと，により港湾に新たに チップの輸入に関連する施設を求めるようになっ た。さらに製紙工場は生産規模の拡大に伴い工場 内に火力発電所を設置するようになり，港湾に新 たに石炭輸入に関連する施設を求めるようになっ た。釧路港はこれらの諸条件を満たした港湾空間 が必要とされた。

Wrenn（1986）は港湾の物流変化への対応とし て, “既存港湾の前面海域の埋め立てによる港湾拡 張”と “新港の建設”の 2 つをあげている。北海 道中央部では小樽港や室蘭港に加えて, 苫小牧港 や石狩湾新港を新たに建設することによって物流 の変化に対応したが, 釧路港は新釧路川の西側に 続く砂浜海岸に港湾を拡張することによって対応 した。これはこの地の背後に原野が広がっていた ため, 港湾用地の確保が比較的容易であったこと もあるが，釧路市自体が釧路港の最大の背後地で あったことによるところも大きいと考えられる。 内陸部の都市や地域を最大の背後地とし, その外 港的役割の大きかった道央圈の諸港湾との違いが ここにみられる。

新港である西港区は, 1974 (昭和 49) 年に石油 栈橋の使用を開始し, 1995 年に最後の埠頭である 第三埠頭の埋め立てを完了した。西港区の建設に 伴い東港区で取り扱われていた貨物は順次西港区 へ移動した。1997 年度現在, 西港区の取扱貨物 （フェリー貨物を除く）は釧路港全体の $74.8 \%$ 占 めている。以下, 図 6 を基に 1998 年現在におけ る西港区の港湾空間の特徵を埠頭ごとにみていく。

第一埠頭の石油栈橋では, 石油製品と重油の移 入が行われている。石油栈橋の背後には石油タン クが 50 基（貯蔵能力 $189,000 \mathrm{kl}$ ） あり, 釧路港 最大の石油配分基地の役割を果たしている ${ }^{11)}$ 。石 油は栈橋から輸送パイプにより石油タンクに保管 あるいは自動車輸送により背後圈へ搬送されてい る。また，一部は石油タンクに隣接している鉄道 (釧路開発埠頭)によって背後圈へ搬送されてい る $^{12)}$ 。

第一埠頭の埠頭部では, 主としてチップの輸入 と紙・パルプの移出が行われている。このうち, チップは第一埠頭の埠頭部での取扱貨物量の 


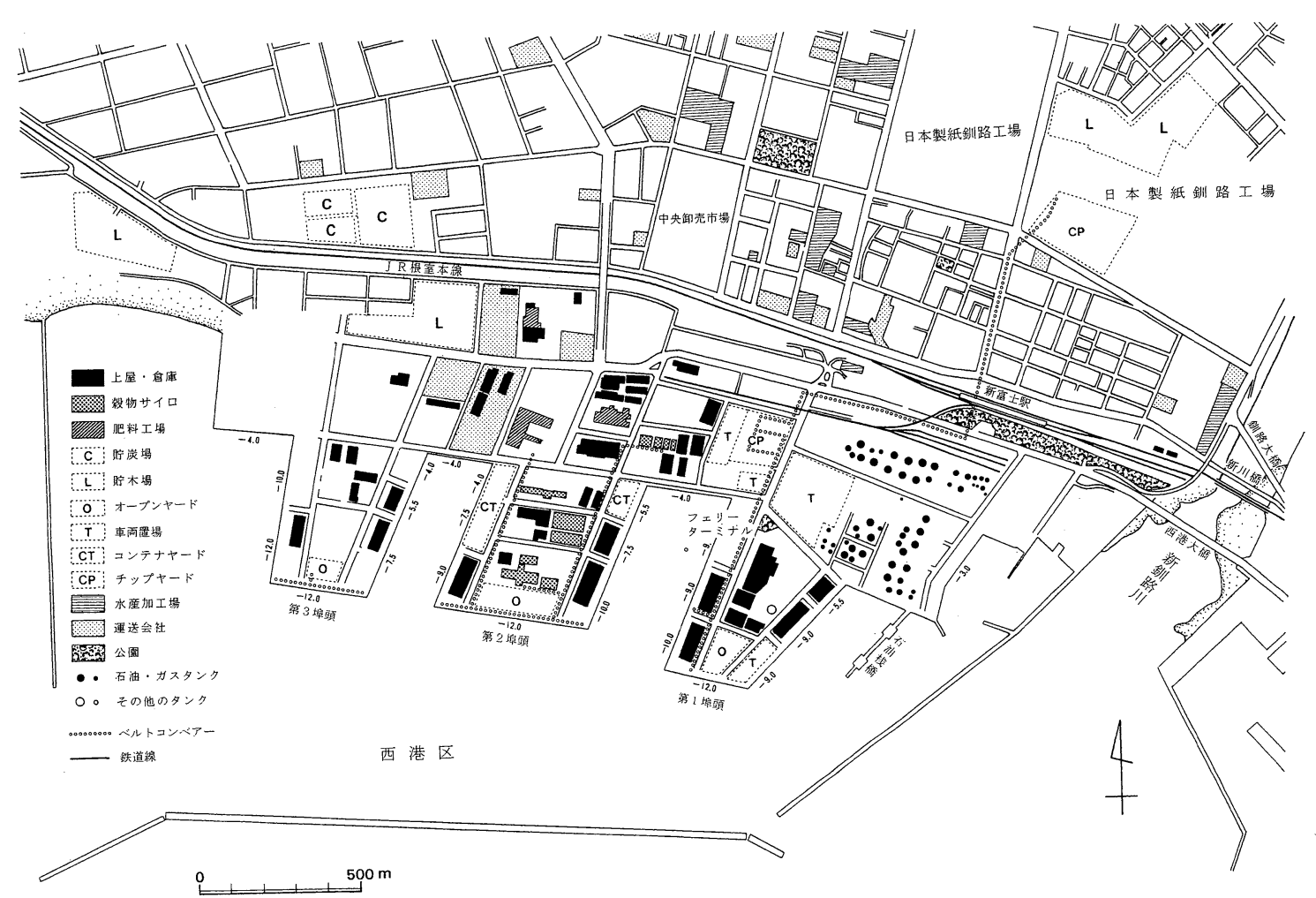

図 61998 年における西港区の土地利用.（現地調查および住宅地図等により作成） 数値は岸壁の水深 $(\mathrm{m})$ を示す.

Fig. 6 Land use of west port in 1998.

63.0\%を，紙・パルプは $11.4 \% を$ 占めている。 チップはチップ輸送専用船からベルトコンベヤー によって埠頭の背後にあるチップヤード（面積 $\left.24,794 \mathrm{~m}^{2}\right)$ へ, チップヤードから日本製紙へはべ ルトコンベヤーで，王子製紙へは貨物自動車に よって搬送されている。一方，製品である紙・パ ルプは両製紙工場から貨物自動車によって主に第 一埠頭東側の岸壁まで搬送され，船積みされてい る。また，第一埠頭の西側岸壁にはフェリーター ミナルがあり，東京港と結ばれている ${ }^{13)}$ 。その他， 埠頭内には上屋 4 棟, 倉庫 3 棟, セメントサイロ 3 基の他，オープンヤードや車両置場が，またそ れらの背後には広大なトレーラーの車両置場がみ られる。

第二埠頭では，主として米・穀物・豆と動植物 性製造飼肥料の輸入，紙・パルプの移出が行われ
ている。このうち米・穀物・豆と動植物性製造飼 肥料の合計は第二埠頭での取扱貨物の $37.8 \%$, 紙・パルプは $18.2 \%$ 占めている。このうち家畜 用飼料は穀物輸送専用船から岸壁の背後に張りめ ぐらされたベルトコンベヤーによって埠頭内ある いは埠頭背後にある穀物・飼料サイロまで運搬さ れている。穀物・飼料サイロは全部で 152 基, 貯 蔵能力は 99,680 トンで, これは東北地方以北で最 大の規模である。穀物・飼料サイロ群の背後には, 大手の運送会社の事務所，倉庫，車両置場および 配合飼料の工場が広大な面積を占めている。飼料 に次ぐ取扱量である紙・パルプは日本・王子の両 製紙工場から貨物自動車によって第二埠頭東側の 岸壁まで運搬され，船積みされている。また，第 二埠頭東側の岸壁にはコンテナヤードが設置され ており, 主として雑貨の移入と砂糖, 澱粉, 野菜 
など背後圈の農産品抢よび農産加工品の移出が, コンテナ専用船や RORO 船 ${ }^{14}$ により行われている。 第三埠頭では，主として生乳の移出と石炭の輸 入が行われている。生乳は第三埠頭での取扱貨物 量の約 $60.7 \%$, 石炭は $18.4 \%$ を占めている。生 乳はタンクローリーによって第三埠頭西側の岸壁 および岸壁背後の生乳ヤードまで搬送され，生乳 運搬専用船に積み达まれている。石炭は石炭輸送 専用船から第三埠頭南側の岸壁に荷揚げされ, 貨 物自動車によって JR 根室本線の北側にある貯炭 場へ運搬されている。原木は第三埠頭の取扱貨物 量の $1.9 \%$ を占めるにすぎないが, 埠頭の背後や西 港区の西に位置する貯木場に運搬されている。そ の他，淖頭内には上屋が 3 棟，倉庫が 2 棟みられ るが，まだ整備が完了していないため，埠頭内に は空地が多くみられる。

このように釧路港西港区は港湾空間に占める鉄 道関連施設の割合が低く, 貨物自動車輸送を前提 とした土地利用になっている。その他の特徵とし て, 岸壁から内陸に向加て, 荷役施設, 保管施 設, 運輸関連施設の順に土地利用がほぼ平行して みられること, 埠頭内の荷役施設と保管施設が特 定の産業との関連が強く, 専門埠頭化が進んでい ること, があげられる。前者に関しては, 荷役施 設は岸壁, 栈橋, 埠頭クレーン, エプロンが, 保 管施設は石油タンク，チップヤード，穀物・飼料 サイロ，コンテナヤード，上屋・倉庫が，輸送施 設は車両置場, 運送会社, 鉄道貨物ヤードが, 生 産施設は製紙工場, 飼料工場が該当する。後者に 関しては, 第一埠頭の石油栈橋とその背後は石油 産業に，第一埠頭の埠頭部は製紙業に，第二埠頭 は酪農業に特化している。第三埠頭は整備中であ り，現在は特定の産業に特化していない。

なお, Wrenn のモデルでは新港の特徽としてコ ンテナ化への対応をあげているが，前述したよう に，西港区には第二淖頭にコンテナヤードが設置 されているもののその規模は小さく，またコンテ ナクレーンも設置されていない。釧路港を発着す るコンテナ船は東京・大阪方面を中心に週約 5 便 運航されているだけであり，1993 年の「陸上出入 貨物調查」 ${ }^{15)}$ によると釧路港のコンテナ貨物の取
扱量は全取扱貨物量の $1.2 \%$ にすぎない。これは(1) 釧路港はコンテナ貨物に向かない石炭，石油製品， チップ，穀物など撒積貨物の取扱量が多いこと， (2)コンテナ輸送は外貿雑貨貨物が中心であるが, 釧路港ではこの種の貨物の取扱量が少ないこと， (3)コンテナクレーンを備えた本格的なコンテナ専 門埠頭の建設には莫大な費用がかかること，など が要因として考えられる。このように，釧路港の 背後圈はコンテナ貨物輸送が中心となるような産 業構造になって扔らず, かつコンテナ貨物を生み 出すような人口集積もみられない。従って, 西港 区はコンテナ貨物用ではなく，撒積貨物用として 建設されたものであるといえる。また，これら撒 積貨物の多くは釧路港と背後圈の産業との間で搬 出入されていることから, 西港区は背後圈との慗 がりが強い産業港湾的特徴を有しており, 港湾空 間には背後圈の産業が反映されているといえる。 ただし，十勝・網走支庁管内で生産される農産物 の大部分は地元の十勝港あるいは網走港に搬送さ れて抢り，北海道東部の産業が釧路港の港湾空間 に反映されない例もみられる（酒井，1993）。

\section{IV. 港湾空間の再編}

\section{1）東港区の港湾空間の現況}

新港への港湾機能の移動は旧来の港湾空間の再 編をもたらすものと考元られる。そこで東港区を 対象に, 港湾空間の現況ならびに再編の様子をみ ていく。始めに, 図 7 の土地利用図を基に 1998 年現在の釧路港東港区の港湾空間の特徴を埠頭お よび岸壁ごとにみていく。

釧路港の南端に位置する南埠頭では主として石 炭の移出とセメントの移入が行われている。石炭 は東港区の貨物取扱量の $44.1 \%$ を占めており, 東 港区で最も重要な貨物となっている。石炭の移出 に関連する施設は 1968 年とほほ同じであるが, セ メントに関しては，埠頭内の線路が撤去され，背 後圈への輸送には貨物自動車が用いられている。 南新埠頭では主として石油製品と重油の移入が行 われている。埠頭の背後には石油製品や重油等の 眝蔵施設 (石油タンク 46 基, 貯蔵能力 $72,418 \mathrm{kl}$ ) が集まって扔り，岸壁とはパイプラインによって 


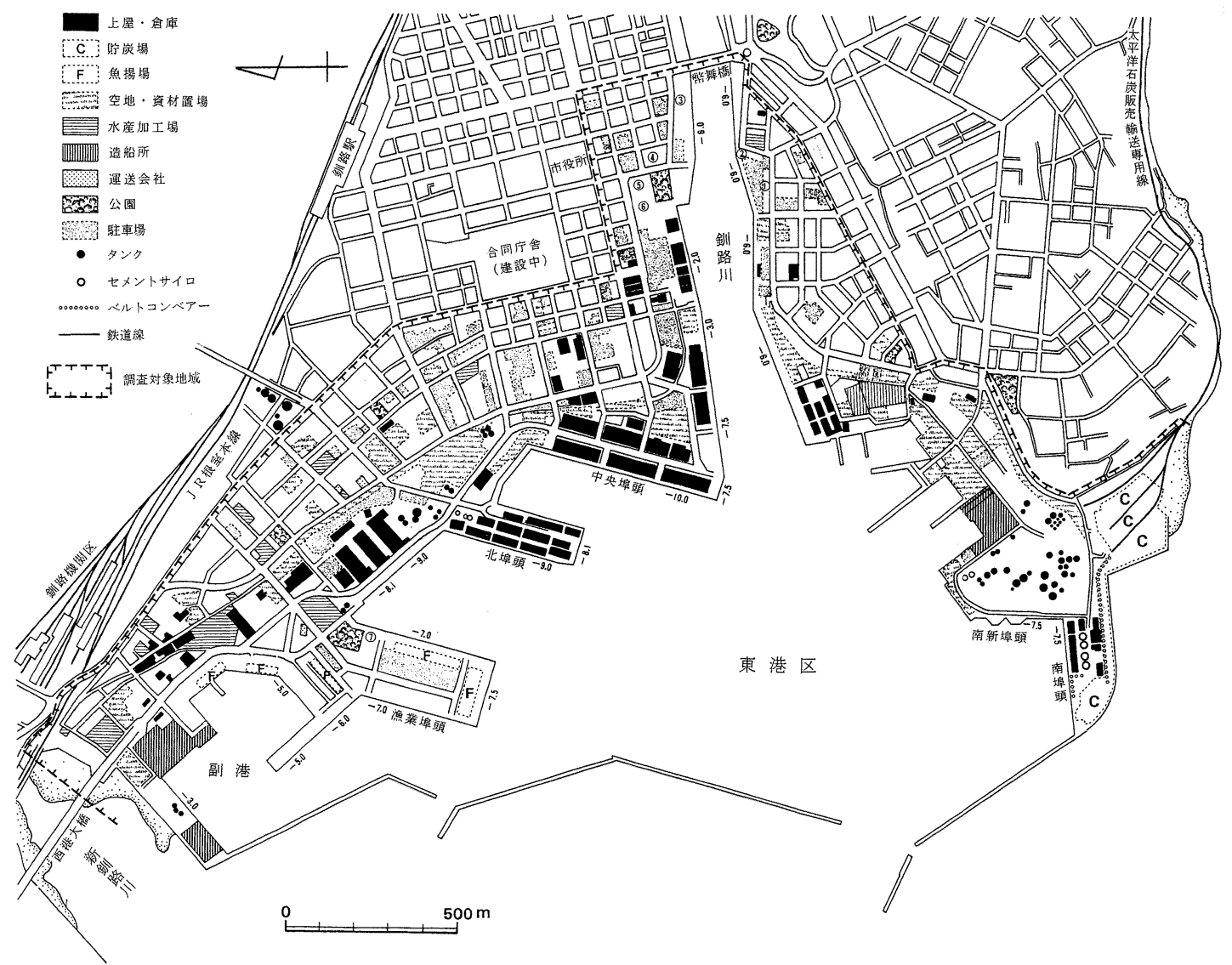

図 71998 年における東港区の土地利用。(現地調查および住宅地図により作成)

数值は岸壁の水深 $(\mathrm{m})$ を示す. (1)釧路ビール, (2)豚木記念館, (3)フィッシャーマンズワーフ MOO, (4)全日空 ホテル，(5)観光国際交流センター，(6)道立釧路芸術館，(7)マリントポス釧路

Fig. 7 Land use of east port in 1998.

結ばれている。南埠頭と南新埠頭は 1997 年現在, 東港区の取扱貨物量の $71.3 \%$ 占め，東港区の中 で最も取扱量が多い。取扱量のうち $94.9 \%$ を石炭, 石油製品，重油が占めており，埠頭および隣接地 はエネルギーに特化した土地利用になっている。

釧路川河口部の岸壁では，ほとんど貨物は取り 扱われていない ${ }^{16)}$ 。河口部のうち, 南新埠頭から 幣舞橋にかけての釧路川左岸では，資材置場，駐 車場，空地など粗放的な土地利用が顕著である。 倉庫や水産加工場が立地しているが，大部分は老 朽化している。しかし，一方で製氷施設が地ビー ルレストランに，鉄道用地の一部が豚木記念館と
して利用されている。幣舞橋から中央埠頭基部に かけての釧路川右岸では, 釧路フィッシャーマン ズワーフ, 国際交流センター, 道立芸術館, ホテ ル，駐車場，公園などが立地している。岸壁では 港湾荷役作業は行われていないが，観光遊覧船の 発着場として利用されている。

中央埠頭では主として原木の輸入と化学肥料の 移輸入が, 北埠頭では主としてセメントの移入が 行われている。しかし, 中央埠頭と北埠頭の東港 区の貨物取扱量に占める割合は各々 $6.3 \%, 4.7 \%$ にすぎない。岸壁に隣接して保管施設が立地して いるが, 老朽化が進んでいる。中央埠頭, 北埠頭 


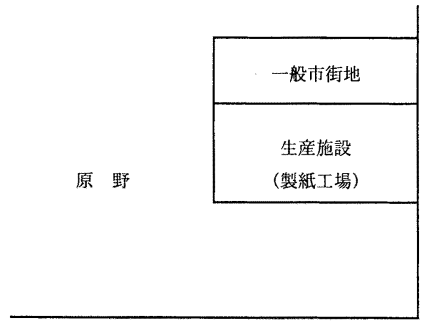

（a）鉄道輸送時代

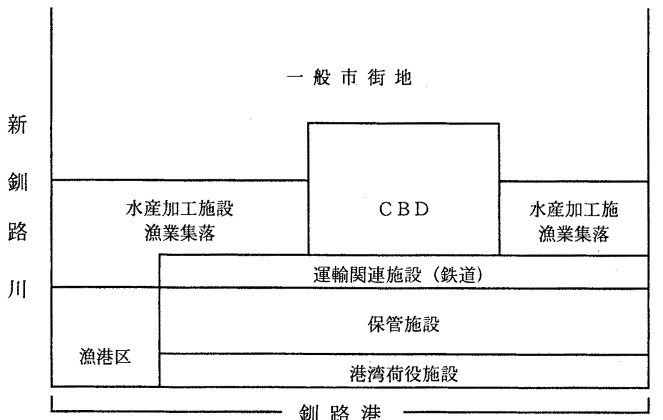

知人岬

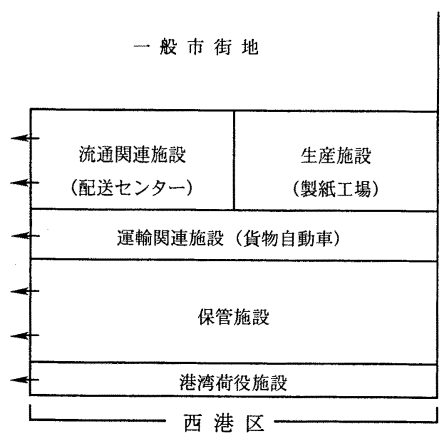

（b）貨物自動車輸送時代

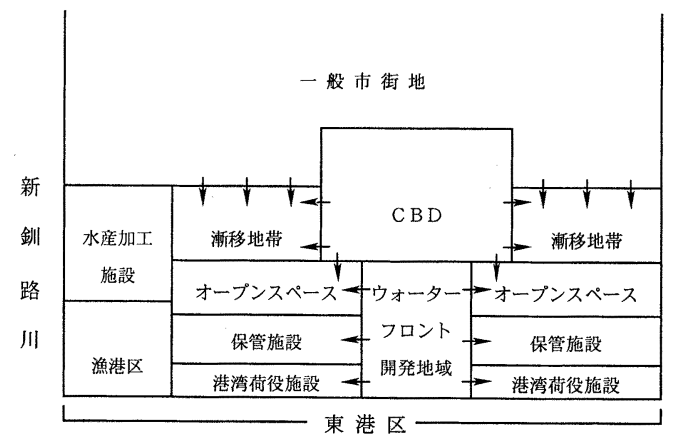

知人岬

図 8 鉄道輸送時代および貨物自動車輸送時代における釧路港の港湾空間と周辺地域. 矢印は拡大の方向を示す。

Fig. 8 Port space and surroundings of Kushiro port in the era of railway dominance and truck dominance.

ともに保管施設の背後は資材置場，駐車場，空地 などの粗放的な土地利用が，さらにその背後の地 域は一般住宅, 中高層マンション, 水産加工場, パチンコ店, 資材置場, 駐車場, 空地などが混在 している。

東港区の北端に位置する漁業埠頭および副港は 漁港として利用されている。その周辺には魚市場, 水産加工場, 冷蔵倉庫など漁業関連の施設が多く みられる。

このように釧路港東港区は, 港域の中央に位置 する釧路川河口部において港湾の物流に関連しな い土地利用が多くみられること, 中央埠頭と北埠 頭の港湾機能は低下し, 背後にはオープンスペー スがみられること, 東港区の南部はエネルギー関
連に，北部は漁業に特化した港湾空間がみられる こと，に特徴がみられる。

\section{2）港湾空間の再編}

図 8 (a) は図 5 を, 図 8 (b) は図 6 と図 7 を 基に, 1968 年と 1998 年の釧路港および周辺地域 を概略化したものである。以下，図 8 の（a）と （b）を比較することによって，釧路港の港湾空間 再編の様子をみていく。

西港区建設に伴う東港区の土地利用の変化は, 明治期から港湾として機能していた釧路川河口部 において最も顕著にみられる。すなわち，旧来の 港湾荷役施設，保管施設，運輸関連施設（鉄道） および漁業関連施設はウォーターフロント開発の 対象となり，施設の大部分が撤去され，新たに商 
業, 業務, 文化, 観光関係の施設が建設されてい る。この地域は, $\mathrm{CBD} に$ 隣接していること, $\mathrm{CBD}$ と同様の機能を有していること, CBD から移転し た施設がみられること, などから CBDのウォー ターフロントへの拡大と捉えることができる。こ の CBD の拡大は, 釧路川河口部が CBD に隣接し ていること, 使用されなくなった港湾施設を転用 することによって広大な用地の確保が可能である こと, また地価が比較的安価であること,によっ て生じたと考えられる。

ウォーターフロント開発地域に接する臨港地区 は，港湾荷役施設の背後に保管施設が位置してお り, 施設配置の面では 1968 年と変化がみられない。 しかし, 西港区の建設により商港としての機能は 低下し, 港湾施設は老朽化が進んでいる。また, 臨港地区と市街地とを分断していた運輸関連施設 (鉄道) は撤去され, 跡地は資材置場, 駐車場, 空 地が広がるオープンスペースとなっている。オー プンスペースはかつての保管施設の卓越した地域 にまで拡大しているが，これは鉄道施設に接して いた倉庫や譻炭場が撤去されたことに伴うもので ある。これらウォーターフロント開発地域に接し た臨港地区の港湾機能はすべて西港区へ移動し, 背後のオープンスペースとともに都市再開発が計 画されている。従って, 港湾空間のうち CBDに 隣接したかつての物流空間は生活空間へと再編さ れつつあるといえる。

一方，ウォーターフロント開発地域から最も離 れた臨港地区（南埠頭・南新埠頭）および漁港区 は, 1968 年と同様, 商港および漁港としての機能 を有している。このうち, 南埠頭・南新埠頭は石 炭や石油の移出入に特化した港湾空間を形成し, エネルギー基地としての役割も果たしている。漁 港区は漁港としての機能を有するとともに, 周辺 地域に水産加工・保管施設の拡大をもたらし ${ }^{17)}$, 漁港区とその背後に漁業に特化した空間を形成し ている。

また, 港湾と一般市街地の間に位置していた漁 業集落では, 空地や駐車場の増加がみられる。こ れは, 集落内の水産加工場の中には施設拡大ある いは悪臭問題等により, 郊外に移転したり廃業す
るものが現れたことや漁業従事者が郊外に移転し たことによる。この地域は現在も漁業従事者が居 住しているが, 一方で一般住宅や高層マンション や娛楽施設の進出が著しく, 漁港との関係が弱ま りつつある。このように, かつての漁業集落は, 土地利用の変化が激しい漸移地带となり, 次第に 一般市街地との区別が困難になってきている。

以上みてきたように，東港区の中心部（釧路川 河口部, 中央埠頭, 北埠頭) は, 商港としての港 湾空間の縮小と CBD および一般市街地の拡大が みられる。これに対して, 東港区の周辺部（南埠 頭・南新埠頭, 副港) はエネルギーおよび漁業に 特化した港湾空間が形成されている。従って, 物 流空間としての港湾は西港区および東港区の両端 部に集約され，ここに生活空間としての都市と物 流空間としての港湾の分離がみられるようになっ たと考えられる。都市と港湾の分離については, 大規模港湾を対象としたWrennの港湾発達モデ ルに抽ても示されているが，前述したように Wrenn は分離の要因としてコンテナ化をあげて いる。しかし，コンテナ化が主流となっていない 釧路港をはじめとする地方港湾においても都市と 港湾の分離は一般的傾向としてみられるが ${ }^{18)}$, こ れはこれまで述べてきたように港湾背後圈の輸送 手段と産業構造の変化, 船舶の大型化と専用船化 およびそれに伴う埠頭の専門化によるところが大 きい。従って, 都市と港湾の分離は大規模港湾の みにみられる現象ではなく, またコンテナ化のみ に起因するものでもない。

\section{V. 結 論}

本研究では, 地方港湾の事例として釧路港を取 り上げ，港湾空間の形成過程および港湾空間に変 化をもたらした要因を明らかにすることを目的と した。その結果, 釧路港の港湾空間の形成につい て，以下のことが明らかになった。

（1）鉄道開通前の釧路港は海岸部のやや湾入し た部分が泊地として利用され, 自然浜で荷役作業 が行われていた。それが, 釧路を起点とする鉄道 の延伸とともに, 艀用の岸壁が鉄道の貨物ターミ ナル付近に成立した。 
（2）大正期から昭和初期にかけての内陸部開拓 の進展と鉄道網の整備により，釧路港の取扱貨物 は増大した。釧路川下流部では専門岸壁化が進行 し，港湾空間は釧路川河口部から上流方向に向 かって拡大した。岸壁は鉄道輸送を前提に整備さ れたため，鉄道と港湾の一体化をもたらしたが， このことは港湾を市街地から分離するとともに漁 業集落の移転をもたらした。

（3）第二次世界大戦後, 移出貨物が飛躍的に増 大したが，釧路港は本船接岸荷役が可能であり， 鉄道輸送に対応した埠頭を市街地前面の海岸部に 建設することによって対応した。新たな埠頭は(1) 広大な鉄道用地が確保されていること, (2)石炭関 連施設の割合が大きいこと, (3)漁港を中心に漁業 および水産加工業に特化した空間が形成されてい ること，に特徵がみられる。

（4）1960 年代中頃に始まるモータリゼーション の進展と背後圈の産業構造の変化および船舶の大 型化と専用船化に対して, 釧路港は既存の港湾に 隣接して新港を築くことで対応した。この新港は (1)貨物自動車輸送に対応した広大な輸送空間を有 していること，(2)岸壁から内陸に向かって，荷役 施設，保管施設，輸送施設の順に土地利用がほぼ 平行してみられること，(3)石油業，製紙業，酪農 業に特化した専門埠頭を有していること，に特徵 がみられ。

（5）新港の建設に伴い，旧港の港湾空間のうち CBD に隣接した地域ではウォーターフロント開 発が行われるようになった。一方，物流空間とし ての港湾は旧港の両端部に限られ，ここにエネル ギーおよび漁業に特化した港湾空間を形成した。 それ以外の港湾空間は施設の老朽化やオープンス ペース化が進行している。

以上の結果を基に, 地方港湾の港湾空間形成の パターンについてまとめる。

開拓期の港湾は一般に天然の良港と呼ばれる湾 奥や河口などに形成されたが，港湾の取扱貨物量 は少なく，貨物の荷役作業は自然浜で行われた。 そして，自然浜に接して市街地の形成がみられた。

鉄道の開通により，鉄道輸送に対応した艀用岸 壁が整備された。艀用岸壁は艀が安全に停泊でき
る場所に建設されたが，海岸部にそれが得られな い場合は河川の河口域を利用することによって対 応した。これに伴い港湾空間の移動あるいは拡大 がもたらされた。なお，大規模な防波堤建設によ る静穏な水域の確保は多大な費用がかかるため, 一般にこの時期には地方港湾ではみられない。

鉄道ネットワークの整備と背後圈の産業の発展 は港湾取扱貨物を増大させ，鉄道に対応しかつ本 船接岸可能な埠頭の整備をもたらした。これに伴 い, 従来の艀用岸壁は順次廃止され, 港湾空間は 市街地前面の海岸部を埋め立てることによって建 設された埠頭へと移動した。なお，この新埠頭の 背後には鉄道関連施設が設置されたため, 港湾空 間は市街地から分断されることになった。

陸海の輸送手段と背後圈の産業構造の変化は, 既存の港湾に隣接した場所に貨物自動車輸送に対 応しかつ専門埠頭化した新港あるいは新埠頭の建 設をもたらした。旧港は CBDに隣接した地域が ウォーターフロント開発の対象となり, CBD と の一体化がみられるようになった。一方，旧港の うち CBD から離れた地域では専門埠頭化が進行 した。このように, 物流空間としての港湾は新港 および旧港の両端部に集約され，ここに生活空間 としての都市と物流空間としての港湾の分離がみ られるようになった。

最後に今後の課題についてまとめる。まず, 本 研究での地方港湾の港湾空間形成のパターンは釧 路港を事例に導いたものである。従って, 今後さ らに他港湾との比較検討を進めていく必要がある。 また, 本研究ではウォーターフロント開発を CBD の拡大と捉えたが, 釧路市の CBD 自体は他の地方 都市と同様に空洞化が著しい。ウォーターフロン 卜開発が郊外化と同様に CBD の空洞化を促進し たのか, あるいは CBD 再生の一現象なのか, に ついて言及しなかった。今後, ウォーターフロン 卜開発と CBD との関係についての実証的研究が 必要である。

\section{謝 辞}

本稿を作成するにあたり, 筑波大学地球科学系の斎藤 功教授ならびに手塚 章教授からは終始, 有益かつ懇切 
なご指導と暖かい激励を賜わりました。さらに, 高橋 伸夫教授, 田林 明教授, 村山祐司助教授をはじめとす る諸先生方からも, 数多くの有益なご示唆とご助言をい ただきました。また，現地調査にあたっては，釧路市， 北海道開発局, 北海道庁の港湾関係機関の方々をはじめ, 多くの方々にご協力をいただきました。以上，末筆なが ら，記して深く感謝の意を表します。

\section{注}

1）港湾の勢力の及ぶ範囲をあらわす用語として“背後 圈”を用いるが, これは“後背圈 (後背地)”と同義 語であり，ともに“hinterland”の邦訳である．港湾 関連の論文では一般に“背後圈”が使用されているの で，本研究においても“背後圈”を使用することにす る。

2）港湾区域とは港湾のうち水域部分を指し, 航路, 泊 地，船だまりなどが含まれる．臨港地区とは港湾のう ち陸域部分を指し, 岸壁, エプロン, 上屋, 倉庫, 臨 港交通施設（道路や鉄道）などが含まれる.

3）本研究での北海道東部とは釧路支庁，十勝支庁，根 室支庁，網走支庁の 4 支庁とする.

4）蝦夷地の領主である松前藩の松前氏は海岸にある集 落を領主值領地と家臣の給与地に分け,「場所」と呼 んでいた。

5）安政 4 年に 4,600 石の交易があったが，そのうち昆 布は 3,500 石, 鰊粕は 500 石, 塩鮭は 360 石であった。 6） 1917 (大正 6）年の釧路・厚岸間の根室線開通に伴 い, 釧路駅は現在の位置に移転し, これまでの釧路駅 は貨物専用駅となり浜釧路駅と改称した。

7） $1966 （$ 昭和 41）年の雄別炭鉱鉄道埠頭線の取扱貨 物量は 1,464 千トンで, このうち石炭が 963 千トン, 石油が 207 千トン, その他が 294 千トンであった.

8）民間が建設, 保有する埠頭を専用埠頭, 特定の貨物 を専門に取り扱う埠頭を専門埠頭という.

9）主流となりつつあった 3 万重量トン級の貨物船は水 深 $12 \mathrm{~m}$ の岸壁を必要としたが, 当時の釧路港の岸壁 は最深でも $10 \mathrm{~m}$ であった。

10）ある港湾で取り扱われている貨物の移出入先および 移輸入先をその港湾の前方圈という.

11） 1997 年現在，第一埠頭で取り扱われる石油製品は 取扱量で釧路港全体の $64.1 \%$, 重油は $62.9 \%$ を占めて いる.

12）釧路開発埠頭は 1999 年 8 月 30 日に鉄道事業を廃 止した. 廃止以降, 西港区では鉄道による貨物輸送は 行われていない.

13）旅客数減少のため, 1999 年の 9 月末でフェリーの 運航は中止され, それにかわって貨物専用の RORO 船 が運航されている.

14）トレーラーやフォークリフトで荷役のできる貨物船.

15）運輸省運輸政策局情報管理部が, 港湾と背後地との 間の貨物流動について行った調査. 港湾の開発, 利用 および管理に資することを目的としている.

16） 1997 年度は入船町岸壁において, その他食料品が 1,250 トン, 鉄鋼が 690 トン移出されている.
17）例えば，雄別炭鉱の貯炭場跡地は水産物の大型冷蔵 倉庫に転用されている.

18）北海道では 1982 年に供用を開始した石狩湾新港を 除くすべての重要港湾においてみられる.

\section{文献}

Bird, J. (1963): The major seaports of the United Kingdom. Hutchison, London, 454p.

遠藤幸子 (1986): 自動車輸送と港湾機能の変化. 港湾経 済研究, 24, 141-151.

Forward, C.N. (1967): Recent changes in the form and function of the port of St. John's, Newfoundland. Can. Geogr., 11, 101-116.

Forward, C.N. (1969): A comparison of waterfront land use in four Canadian ports : St.John's, Saint John, Halifax, and Victoria. Econ. Geogr., 45, 155169.

布施 正 (1994): 釧路港. 釧路市, 336p.

Hance, W.A. and van Dongen, I.S. (1956): The port of Lobiito and the Benguela railways. Geogr. Rev., 46, $460-487$.

Hance, W.A. and van Dongen, I.S. (1957): Lourenco Marques in Delagoa Bay. Econ. Geogr., 33, $238-$ 256.

Hance, W.A. and van Dongen, I.S. (1958a): Matadi, focus of Belgian African transport. Ann. Ass. Amer. Geogr., 48, 41-72.

Hance, W.A. and van Dongen, I.S. (1958b): Dar Es Salaam, the Port and its tributary area. Ann. Ass. Amer. Geogr., 48, 419-435.

伊藤達雄 (1995): コンテナ港湾としての四日市港の形成 と展開. 港湾研究, 16, 51-79.

寒地港湾技術研究センター (1998): 釧路港建設史. 北海 道開発局釧路開発建設部釧路港湾事務所, 389p.

河地貫一 (1974) : 地方港湾における港湾機能の変遷一長 崎港の場合一. 港湾経済研究, 12, 1-18.

Kenyon, J.B. (1968): Land use admixture in the built-up urban waterport: Extent and implications. Econ. Geogr., 44, 152-177.

北見俊郎 (1993): 港湾都市. 成山堂, 144-146p.

今野修平 (1970): 港湾施設の近代化と背後地との関係一 博多港穀物埠頭を例として一. 東北地理, 22, 85-91.

今野修平 (1983): 港湾の変貌と都市. 都市問題研究, 35-5, 72-84.

柾 幸雄 (1968): 港湾と都市の形成発展. 都市問題研究, 20-7, 17-28.

奥平忠志 $(1967)$ : 港湾と都市の変遷一函館の場合一. 東 北地理, 19, 102-108.

奥平忠志・南 時久 (1966): 北海道の港湾都市の 4 つの 比較研究. 東北地理, 18, 62-69.

Rimmer, P.J. (1967): The search for spatial regularities in the development of Australian seaports 1861-1961/2. Geogr. Ann., 49B, 42-54.

Rimmer, P.J. (1967): Changes in the ranking of Australian sea-ports 1951-2 - 1961-2. Tijdschrift 
Voor Econ. en Soc. Geografie, 58, 28-38.

Rimmer, P.J. (1967): The changing status of New Zealand sea-ports, $1853-1960$. Ann. Ass. Amer. Geogr., 57, 88-100.

酒井多加志 (1993): 北海道東部太平洋岸における主要港 湾と後背地. 北海道ウォーターフロント研究, $3,7-$ 14.

酒井多加志 (1996): 釧路港を中心とする輸送ネットワー クの形成過程. 人文地理学研究， 20, 291-306.

佐藤大祐・中村昭史・山下亜紀郎・田林 明 - 日野敬 仁・脇田政人・飯島容平 (2000): ひたちなか市那珂湊 における漁業空間の構造. 地域調査報告, 22, $171-$ 206.

Scott, P. (1959): The Australian CBD. Econ. Geogr., 35, 219-314.
柴田悦子（1998）: 物流と港湾都市．都市問題研究，50$7,42-54$.

Shinohara, S. (1992): Fishing space of main fisheries at Choshi fishing port. Sci. Reps. Inst. Geosci., Univ. Tsukuba, Sec.A, 13, 59-86.

Wallace, I. (1975): Containerization at Canadian ports. Ann. Ass. Amer. Geogr., 65, 433-448.

渡辺四郎 (1971): 東北地方の港湾. 東北地理, 23，6877.

Wrenn, D.M. 著，横内憲久監訳 (1986): 都市のウォー ターフロント開発. 鹿島出版会, 220 p.

山口平四郎 (1980): 港湾の地理. 古今書院, 339p.

(2001 年 6 月 4 日受付, 2001 年 12 月 17 日受理) 